10. Там само, Спр. 300.7 арк.

11. Там само. Спр. 949.75 арк.

\section{REFERENCES}

1.Hrushevskyi, M. (1909). Nasha shkola [Our school]. p.1.Vol.1-2.pp. 1-5. [in Ukrainian].

2. Nahachevska, Z. (2007). Pedahohichna dumka $i$ prosvitnytstvo $v$ zhinochomu rusi Zakhidnoi Ukrainy (druha polovyna XIX st. 1939 r.) [Pedagogical thought and enlightenment in the women's movement of Western Ukraine (second half of the XIX century 1939)]. IvanoFrankivsk, 767 p. [in Ukrainian].

3. Khronika NTSh (1905). [Chronicles Shevchenko Scientific Society]. Lviv, Vol. 24. p. 3. [in Ukrainian].

4. Khronika NTSh (1922). [Chronicles Shevchenko Scientific Society]. Lviv,Vol. pp.65-66, p. 9.

5. Tsentralnyi derzhavnyi istorychnyi arkhiv Ukrainy, m. Lviv [Central State Historical Archive of Ukraine, Lviv]. F.309. Op.1. Spr. 122.17 ark. [in Ukrainian].
6. Tsentralnyi derzhavnyi istorychnyi arkhiv Ukrainy, m. Lviv [Central State Historical Archive of Ukraine, Lviv]. F. 309. Op. 1. Spr. 281. 18 ark. [in Ukrainian].

7. Tsentralnyi derzhavnyi istorychnyi arkhiv Ukrainy, m. Lviv [Central State Historical Archive of Ukraine, Lviv]. F. 309. Op. 1. Spr. 282. 29 ark. [in Ukrainian].

8. Tsentralnyi derzhavnyi istorychnyi arkhiv Ukrainy, m. Lviv [Central State Historical Archive of Ukraine, Lviv]. F. 309. Op. 1. Spr. 298. 37 ark. [in Ukrainian].

9. Tsentralnyi derzhavnyi istorychnyi arkhiv Ukrainy, m. Lviv [Central State Historical Archive of Ukraine, Lviv] F. 309. Op. 1. Spr. 299. 18 ark. [in Ukrainian].

10. Tsentralnyi derzhavnyi istorychnyi arkhiv Ukrainy, m. Lviv [Central State Historical Archive of Ukraine, Lviv]. F. 309. Op. 1. Spr. 300.7 ark. [in Ukranian].

11. Tsentralnyi derzhavnyi istorychnyi arkhiv Ukrainy, m. Lviv [Central State Historical Archive of Ukraine, Lviv]. F. 309. Op. 1. Spr. 949. 75 ark. [in Ukrainian].

Стаття надійшла до редакції 03.04.2019

УДК 378.014.252

DOI:

Василь Трущак, викладач японської мови Національного університету “Львівська політехніка"

\title{
ВИКОРИСТАННЯ АУДІОВІЗУАЛЬНИХ МАТЕРІАЛІВ У ВИКЛАДАННІ ЯПОНСЬКОӦ МОВИ
}

У статті розглянуто види і можливості аудіовізуальних матеріалів і їх використання у викладанні японської мови. Визначено трактування терміну “аудіовізуальні матеріали”, досліджено класифікації аудіовізуальних матеріалів. Відповідно до иієї класифікації показано ресурси, де вони можуть бути доступними. Особливо детальному аналізу піддаються відеоматеріали $i$, зокрема, аніме як особливий вид відеоматеріалів. В роботі пояснено особливості його використання у викладанні японськоїмови, обтрунтовано його важливість, пояснено основні проблеми, які виникають при його використанні і способи їх вирішення.

Ключові слова: аудіовізуальні матеріали; викладання японської мови; візуальні засоби; адитивні засоби; навчальні відеоматеріали; аніме.

Jim. 5.

Vasyl Truschak, Lecturer of the Japanese National University of "Lviv Polytechnic"

\section{THE USE OF AUDIOVISUAL MATERIALS \\ IN THE TEACHING OFTHE JAPANESE LANGUAGE}

The article deals with the types and possibilities of audiovisual materials and their use in the teaching of the Japanese language. The interpretation of the term "audiovisual materials" has been determined, and the classification of audiovisual materials has been studied. According to this classification, resources are shown where they can be accessed. Particularly detailed analysis is exposed to video materials and, in particular, anime as a special kind of video material. The paper explains the peculiarities of its use in teaching the Japanese language, substantiates its importance, explains the main problems that arise when it is used and how to solve them. Especially since modern students are the generation, brought up completely under the influence of information technology. Any promising education system can no longer focus only on the teacher as the sole source of educational information. Today, his role is, first of all, in organizing the cognitive process, the comprehensive development of students. Modern trends in the development of information technologies dictate the need to expand the forms, methods and means of learning through the widespread use of modern electronic information and communication approaches. Their application in the educational process can significantly increase the efficiency of the visibility in teaching, to more fully and accurately inform students about the object being studied or phenomenon. That is why, the study of the use of audiovisual media becomes particularly relevant. Moreover, their application is very extensive - as a supplementary 


\section{ВИКОРИСТАННЯ АУДІОВІЗУАЛЬНИХ МАТЕРІАЛІВ У ВИКЛАДАННІ ЯПОНСЬКОЇ МОВИ}

material for the study of lexical material and Japanese writing (both hieroglyphics and cannabis), grammatical material (to a lesser extent, but also used) as auxiliary material for types of linguistic activities not related with the use of these tools, as well as for the development of language templates with passive listening, as we see it when using the anime.

Keywords: audiovisual materials; teaching of Japanese language; visual means, addictive means; educational videos; anime.

П

остановка проблеми: Сучасні студенти - це покоління, виховане повністю під впливом інформаційних технологій. Будь-яка перспективна система освіти вже не може орієнтуватися тільки на викладача як на єдине джерело навчальної інформації. Сьогодні його роль полягає, перш за все, в організації пізнавального процесу, всебічному розвитку студентів. Сучасні тенденції розвитку інформаційних технологій диктують необхідність розширення форм, методів і засобів навчання за рахунок широкого використання сучасних електронних інформаційно-комунікативних підходів. Їх застосування в навчально-виховному процесі дозволяє значно підвищити ефективність наочності в навчанні, повніше й точніше інформувати студентів про досліджуваний об'єкті або явище [1]. Особливої важливості застосування аудіовізуальних засобів набуває при вивченні іноземних мов, зокрема і японської мови. Разом $з$ цим, можливості і способи застосування аудіовізуальних засобів на заняттях 3 японської мови не $€$ достатньо дослідженими, що зумовлює актуальність даного дослідження. Метою даного дослідження є виділення аудіовізуальних засобів, які вживаються у викладанні японської мови і пояснення їх застосування в практичній педагогічній діяльності.

Аналіз основних досліджень та публікацій. Публікації та дослідження на тему аудіовізуальних матеріалів необхідних для викладання японської мови та їх застосування відсутні, проте наявні дослідження щодо аудіовізуальних навчальних матеріалів в цілому. За Григор'євим, аудіовізуальні засоби - це особлива група засобів навчання, що використовується для передачі та сприйняття інформації, зафіксованої на різних запам'ятовуючих пристроях (кіноплівках, аудіо плівках, компактних дисках і таке інше) та на друкованих основах (схемах, таблицях, діаграмах, графіках, репродукціях картин тощо). Деякі науковці вважають, що ці засоби спрямовані на підвищення ефективності сприйняття навчального матеріалу, перевірки рівня його засвоєння, опанування вміннями та практичними навичками застосування отриманих знань, а також різноманітних засобів механізації трудомістких процесів, що відбуваються у процесі навчання [2]. Комарова зазначає, що за класифікацією
М. Ляховицького існує три типи аудіовізуальних засобів:

1. Візуальні (зорові) - малюнки, таблиці, схеми, репродукції картин, діафільми, діапозитиви і таке інше;

2. Адитивні (слухові) - фонозаписи, радіотрансляції тощо;

3. Власне аудіовізуальні (зорово-слухові) кінофільми, телефільми, діафільми із звуковим супроводженням, комп'ютерні програми і таке інше.

Іншою класифікацією аудіовізуальних засобів навчання є класифікація Зельманова, яка включає екранні, звукові і екранно-звукові засоби [3]. У цій роботі буде застосовано класифікацію Ляховицького, так як для япономовного матеріалу більш важливим $€$ вид сприйняття матеріалу ніж спосіб його відображення.

Мета статті. Визначити і показати специфіку застосування аудіовізуальних матеріалів у викладанні японської мови.

Виклад основного матеріалу. Візуальні матеріали на заняттях 3 японської мови представлені зображеннями 3 поясненням написанням складових азбук та ієрогліфів і допоміжними зображеннями для запам'ятовування слів і граматичних конструкцій. Прикладом таких матеріалів $є$ відео $з$ поясненням написання азбук катакана і хірагана на уoutube.com. Щодо ієрогліфіки, то одним 3 найкращих прикладів пояснення написання $є$ анімовані написання ієрогліфів в програмі Kanji Odyssey [5], де вони поділені на рівні за частотою вживання i складністю написання. Застосування цих анімацій дозволяє уникнути помилок, яких може допустити викладач при самостійній демонстрації написання ієрогліфів. Зокрема, ї використання дає можливість студентові побачити написання символів на великому екрані замість спостережень за дошкою, де не завжди може бути видно як процес написання так і кінцевий результат. Також це унеможливлює помилку викладача як щодо кількості і напрямку так $\mathrm{i}$ порядку написання штрихів, що є дуже важливим, особливо на початковому етапі вивчення японського письма. Крім того, студент завжди може відтворити ці зображення завантаживши програму, отримавши посилання або, в випадку відсутності доступу до цих ресурсів, записавши відео прямо 3 екрану де демонструється 
написання. Крім анімованих матеріалів використовуються і зображення, де кожне наступне зображення показує наступний крок при написанні символу. Такі матеріали потребують додаткових пояснень викладача, і при виникненні особливих труднощів також і демонстрації від викладача, проте володіють тими ж перевагами, що й анімовані матеріали. Цікавим прикладом $\epsilon$ зображення з сайту memrise.com., де у курсах Basic Hiragana i Basic Katakana вони використовуються для кращого запам'ятовування складових азбук. I хоча тут йдеться мова про англомовний ресурс і приклади нерідно мають прив'язку до англійської мови (наприклад для знака (ki) використовується малюнок ключа, так як англійське слово "kеy" так само читається i має значення ключ), проте практика показує, що для студентів це не становить жодної проблеми.

Прикладом візуальних матеріалів для запам'ятовування слів і граматичних конструкцій $\epsilon$ сайт mlcjapanese.co.jp. - онлайн ресурс Токійської мовної школи MLC, де окрім чіткого поділу слів на модулі по темах відповідно до рівня студента, для покращення запам'ятовування матеріалу використовуються малюнки, текст різного кольору, тощо. В поєднанні з власне аудіовізуальними матеріалами 3 цього ж ресурсу, про які мова піде нижче, можна досягти значного покращення в запам'ятовуванні матеріалу. Особливо варто виділити зображення для запам'ятовування хвилин, так як окрім самих слів i їх перекладу також демонструється позиція губ при говорінні, що допомагає краще зрозуміти спосіб вимови подібних за звучанням слів [4]. Також, візуальними матеріалами для запам'ятовування слів можугь буги складені викладачем презентації, де слова, які треба вивчити супроводжуються відповідними зображеннями. Таким чином будується асоціативний зв'язок між зображеннями і словами, що дозволяє студенту краще запам'ятовувати ці слова.

Аудитивні матеріали на заняттях 3 японської мови представлені аудіо матеріалами з підручника і матеріалами типу подкастів. При застосуванні аудіоматеріалів важливим $є$ комбінування цих матеріалів, так як нерідко вони можуть бути різноплановими і нести в собі різні освітні цілі. Наприклад, аудіо матеріали підручника Minna no nihongo Японська для всіх дає можливість досягти студентам розуміння того як вивчені раніше в цьому ж підручнику граматичні конструкції реалізовуються в мові, розпізнавати вивчений матеріал, продемонструвати мовленнєві ситуації i будувати шаблони, які можна реалізовувати в реальному спілкуванні. Разом 3 тим, проблемою цих матеріалів є те, що мовці у більшості 3 них спілкуються нейтральноввічливим стилем, тим часом як в реальному спілкуванні набагато частіше використовується розмовний стиль (при повсякденному спілкуванні) а також ввічливий і самопринизливий стилі (при діловому спілкуванні з людиною вищою за статусом, посадою тощо). В межах підручникових матеріалів ця проблема $є$ складною для вирішення, проте якщо долучити до навчального процесу матеріали на зразок подкастів 3 сайту japanesepod101.com., де найбільш вживаним $є$ якраз розмовний стиль, то можна досягти необхідної рівноваги у побудові шаблонів різного стилю мовлення відповідно до мовленнєвої ситуації.

Окрім того, що адитивні матеріали використовуються для розпізнавання знайомої лексики та граматичних конструкцій і побудови шаблонів, інформація отримана 3 цих матеріалів може бути основою для обговорення чи усного спілкування. Наприклад, у підручниковому матеріалі присутні вправи, які містять запитання без відповідей. Студенти повинні не тільки почути і відтворити це запитання, але й дати на нього відповідь. По можливості викладач може задавати додаткові питання студенту відповідно до змісту його відповіді. Таким чином відбувається опитування студентів, при якому викладач одночасно перевіряє і слухові і комунікативні навики студентів. Подібний принцип роботи діє і 3 подкастами, де дається комунікативна ситуація. Після розпізнавання сказаного мовцем у аудіо матеріалі, студентам пропонується розповісти про себе відповідно до того, про що йшлося у аудіоматеріалі. Наприклад, в аудіо матеріалі йдеться про сім'ю - студент розповідає про свою сім'ю; в аудіо матеріалі телефонна розмова студенти в парах складають діалог-телефонну розмову; в аудіо матеріалі мовець розповідає про те що любить чи не любить - студент розповідає те ж саме про себе. За таким принципом викладач має можливість прослухати усіх студентів і покращити їх розуміння матеріалу, при цьому у них одночасно покращуються i слухові i комунікативні навики з японської мови.

Власне аудіовізуальні матеріали представлені відеоматеріалами 3 сайту youtube.com i інших відеоресурсів, уривків японських телепрограм, аніме, тощо. Для зручності, надалі називатимемо їх відеоматеріалами. Серед них можна виділити матеріали, які несуть в собі допоміжну функцію і матеріали, які можуть використовуватися самостійно. Прикладом допоміжних матеріалів $є$ підручників відеоматеріали зі згаданого раніше 
підручника, де відеоматеріали є ілюстративним матеріалом до діалогів $з$ підручника. Тим не менше, відеоматеріали дають можливість додаткової візуалізації ситуації в якій опиняються персонажі цих діалогів, як от інтонація, емоційне навантаження, невербальні засоби комунікації. А це, в свою чергу, полегшує їх сприйняття i урізноманітнює навчальний процес, тому не варто недооцінювати їх важливість. На занятті ці відеоматеріали використовуються для першого знайомства 3 діалогом, даючи студентам можливість зрозуміти мовленнєву ситуацію. Таким чином при читанні діалогу, навіть у випадку, коли сам діалог є доволі складним, студенти після перегляду хоча б частково розуміють про що йдеться. Повторний перегляд може бути застосований при потребі, у випадку, коли потрібно краще зрозуміти інтонацію мовців.

Іншим вдалим прикладом допоміжного відео ресурсу є відеоматеріали зі згаданого раніше сайту mlcjapanese.co.jp. На цьому ресурсі відеоматеріали використовуються для того щоб показати правильну вимову слів. На цих відеоматеріалах японка проговорює слова представлені в межах модуля який вивчається, таким чином демонструючи правильну вимову. При цьому, вона робить паузи, під час яких студенти можуть повторити ці слова. На практиці використання цих відео реалізовується у вигляді трьох переглядів, де у першому студенти пасивно слухають і намагаються запам'ятати особливості вимови слів, у другому викладач ставить відео на паузу після кожного слова i студенти повторяють за японкою сказані нею слова, а у третьому викладач вже не ставить відео на паузу і студенти мають встигнути сказати ті ж слова тоді, коли японка робить паузи, а не коли відео зупиняє викладач (зазвичай при занадто повільній вимові цих пауз недостатньо щоб встигнути вимовити слово, тому це потребує додатково концентрації у студента). В поєднанні 3 зображеннями, враховуючи можливість відтворення цих матеріалів і поза межами аудиторії $\epsilon$ можливість досягнути ще більшого ефекту у вивченні лексики.

Подібно до адитивних матеріалів, відеоматеріали теж можуть бути основою для обговорення чи усного спілкування. При цьому потрібно враховувати відповідність рівня знань мови студентів до складності теми обговорення і складності самого матеріалу, проте в випадку досягнення цієї відповідності, в поєднанні 3 інтересом до теми відео, значно зростає активність студентів на занятті так як найчастіше, при правильному виборі матеріалу студенти виявляють бажання висловити свою думку навіть коли їх рівень мови не є досить високим, але в результаті спроб вони виправляють свої помилки і покращують свій рівень знання мови. Разом 3 тим необхідно досягти якомога більш невимушеної і спокійної атмосфери на занятті щоб студенти мали бажання до активного обговорення і не боялися висловлювати свою думку.

Ще одним важливим і часто недооціненим видом відеоматеріалів $є$ аніме - особливий вид японської мультиплікації. Переважно його розглядають як розважальні відеоматеріали і тому не приділяють досить уваги. Проте, наприклад, в університеті Мейджі створили науково-дослідний інституг манга (японських коміксів) та аніме. Крім цього, варто зазначити, що аніме давно вже вийшов за рамки японської культури і має значний вплив і за межами Японії. Але, незважаючи на це, його частіше розглядають в розважальному аспекті, хоча можна помітити, що воно потребує значно ширшого розгляду так як у ньому проявляються елементи культури і мислення японців, які можна не помітити у інших жанрах не тільки масової культури, а й мистецтва загалом. Враховуючи специфічні як аудіо так і відео складову, аніме надає нестандартний мовний матеріал, який важко буде отримати в інший спосіб в поєднанні з розважальною складовою відеоматеріалу.

Відповідно до цього першим способом застосування аніме $\epsilon$ пасивний перегляд. Можна справедливо зазначити, що якщо в попередніх випадках мова йшла про активність пов'язану з матеріалом, то пасивність може не дати ефекту, проте відсутність чіткого завдання не означає відсутність осмислення того що відбувається на екрані. Навіть навпаки, практика показує, що така ніби то пасивна діяльність доводить до позитивних результатів. Зазвичай мова, яка застосовується у аніме $є$ занадто складною для розуміння студентів молодших курсів, а студенти старших курсів матимуть труднощі, якщо переглядатимуть аніме без перекладу або субтитрів. Звичайно, що для того щоб аніме було навчальним матеріалом необхідною умовою $є$ оригінальна озвучка 3 субтитрами для того щоб розуміти зміст. Разом 3 тим, не маючи потреби шукати переклад, студенти розслабляються і починають більш чи менш свідомо шукати дві складові: те що вони розуміють і те що їм цікаво. Знаходячи те що вони розуміють (а 3 кожним роком навчання таких моментів стає все більше), студент отримає додаткову мотивацію до навчання так як відчуває задоволення від цього і хоче розуміти ще більше. В випадку пошуку того що їм цікаво, а це 


\section{ВИКОРИСТАННЯ АУДІОВІЗУАЛЬНИХ МАТЕРІАЛІВ У ВИКЛАДАННІ ЯПОНСЬКОЇ МОВИ}

найчастіше якісь слова чи висловлювання які мають особливий зміст в контексті цього аніме, вони будуть їх відтворювати 3 характерною інтонацію, імітуючи персонажа, який їх висловлює. 3 допомогою таких висловлювань при інтересі студента до аніме, накопичується цілий набір фраз, які виражають певні складові розмовної мови або складних граматичних конструкцій, які випереджають те, що студент має знати по навчальній програмі або які взагалі у ній відсутні. Через це нерідко буває, що студенти, які до початку навчання в університеті цікавились аніме вчаться краще ніж ті, які вперше побачили аніме на занятті. Викладач же, помітивши інтерес до тих чи інших моментів і їх відтворення може апелювати до тих чи інших епізодів аніме або до конкретних фраз, щодо яких він знає, що студенти їх вивчили.

При цьому, при підборі матеріалу основним критерієм $€$ потенційний інтерес студентів до аніме і навіть можливий варіант, що студенти самостійно виберуть що їм дивитися. Аніме також можна розглядати як матеріал для дискусії, проте ефективним це буде лише зі старшими курсами, у яких рівень мови $є$ достатнім для цього. Більш важливим $\epsilon$ зворотній зв'язок щодо того чи викликав обраний матеріал у студентів, що вони запам'ятали і чим зацікавилися. В окремих випадках викладач може надати пояснення щодо того чи іншого аспекту і надає студентам додаткову мотивацію до навчання. Тобто бачимо, що попри наявність певних недоліків, їх можна усунути, тим часом як користь від використання аніме у викладанні японської мови я досить значною.

При всіх цих перевагах, в застосуванні аніме $€$ і кілька недоліків. Зокрема, не у кожного студента $\epsilon$ мотивація до перегляду аніме через невдалий вибір при самостійному перегляді, антипатії щодо своєрідності зображення чи манери висловлювання акторів озвучки вцілому. І хоча $є$ імовірність, що цей студент змінить свою думку, частіше буває, що він сприймає аніме лише як розважальну складову і продовжуючи перегляд разом $з$ іншими, вже не досягне відповідних навчальних цілей згаданих вище. Крім того викладач має відчувати не менший ентузіазм щодо аніме, інакше ефект може бути дещо гірший від очікуваного, але якщо студенти побачать цей інтерес, то комунікація з ними покращиться. Ще одним мінусом $є$ те, що бажання переглядати аніме постійно може викликати зниження інтересу до інших видів діяльності і негативно впливати на навчальний процес, проте при правильній частоті використання цієї проблеми не виникне.
Також окремої згадки потребують відео, які можуть бути не пов'язані з японською мовою і несуть в собі інформацію країнознавчого, культурологічного характеру, тощо. Навіть якщо вони не містять японської мови, вони корисно впливають на навчальні результати, так як через вивчення культури студенти мають можливість краще зрозуміти мову цієї країни.

Висновки. Отже, відзначаємо, що використання аудіовізуальних матеріалів $є$ необхідною умовою для якісного ведення навчального процесу, так як сучасні студенти це покоління, виховане повністю під впливом інформаційних технологій. Аудіовізуальні засоби - це особлива група засобів навчання, що використовується для передачі та сприйняття інформації, зафіксованої на різних запам'ятовуючих пристроях та на друкованих основах. За класифікацією М. Ляховицького існує три типи аудіовізуальних засобів: візуальні (зорові); адитивні (слухові) і власне аудіовізуальні (зоровослухові). Візуальні матеріали на заняттях 3 японської мови представлені зображеннями 3 поясненням написанням складових азбук та ієрогліфів і допоміжними зображеннями для запам'ятовування слів та граматичних конструкцій і застосовуються для більшої наочності при вивченні лексики, ієрогліфіки і граматичних конструкцій. Аудитивні матеріали на заняттях з японської мови представлені аудіо матеріалами 3 підручника і матеріалами типу подкастів. Вони використовуються як допоміжні елементи при роботі з іншими матеріалами або як основа для обговорення зі студентами. Власне аудіовізуальні матеріали представлені відеоматеріалами 3 сайту youtube.com i інших відеоресурсів, уривків японських телепрограм, аніме тощо. Подібно до адитивних матеріалів, частина з них є допоміжними, також як і наявні ті, які є основою для обговорення зі студентами. Окремо слід відзначити аніме, так як його роль часто $€$ недооціненою, при тому що воно дозволяє студентам отримати знання, частину з яких не передбачено програмою i, разом з тим, добре їх запам'ятати через їхню легкість відтворення, інтерес з боку студента, емоційну складову, тощо. I тому, навіть попри невеликі недоліки аніме варто застосовувати при вивченні японської мови. Також варто відзначити відеоматеріали пов'язані 3 культурою Японії, так як вивчення культури сприяє кращому вивченню мови. Враховуючи малодослідженість даної теми, перспективними $€$ більш детальні дослідження кожного згаданого виду матеріалів 3 розглядом практичного використання більшої кількості ресурсів кожного виду. 

ДОСЯГНЕННЯПРОФЕСІЙНОГО РОЗВИТКУ МАЙБУТНЬОГО ПЕДАГОГА-МУЗИКАНТА

\section{ЛIТЕРАТУРА}

1. Воронін Ю. А. Технічні та аудіовізуальні засоби навчання : навчальний посібник. Воронеж : Воронезький державний педагогічний університет, $2001.232 \mathrm{c}$.

2. Григор'єв С.Г. Мультимедіа в освіті. Москва, 2002.

3. Комарова Н.I. Технічні та аудіовізуальні засоби навчання. Програма для студентів гуманітарних факультетів педагогічних вузів. Москва, 2004.

4. Онлайн ресурс Токійської мовної школи MLC, допоміжні зображення для пояснення лексики. URL: https://www.mlcjapanese.co.jp/n5_01_03.html (дата звернення: 28.03.2018).

5. Kanji Odyssey - демо-версія програми. URL: https://www.coscom.co.jp/ebksample/smp 2001kanji/ index mokuji.html (дата звернення: 28.03.2018).

\section{REFERENCES}

1. Voronin, Yu. A. (2001). Texnichni ta audiovizualni zasoby navchannya : navchalnyj posibnyk [Technical and audiovisual teaching aids: Tutorial]. Voronezh, $232 \mathrm{p}$. [in Ukrainian].

2. Grygoryev, S. G. (2002). Multymedia v osviti [Multimedia in education]. Moscov. [in Ukrainian].

3. Komarova, N. I. (2004). Texnichni ta audiovizualni zasoby navchannya. Programa dlya studentiv gumanitarnyx fakultetiv pedagogichnych vuziv [Technical and audiovisual teaching aids. Program for students of humanities faculties of pedagogical universities]. Moscov. [in Ukrainian].

4. Onlajn resurs Tokijskoyi movnoyi shkoly $M L C$, dopomizhni zobrazhennya dlya poyasnennya leksyky [Online resource of Tokyo language school MLC, auxiliary images for explanation of vocabulary]. [Electronic resource]. Available at: https://www.mlcjapanese.co.jp/ n5_01_03.html (Accessed 28 Mar. 2018). [in English].

5. Kanji Odyssey - demo-versiya program [Kanji Odyssey-program demo-version]. [Electronic resource]. Available at:https://www.coscom.co.jp/ebksample/ smp_2001kanji/index_mokuji.html (Accessed 28 Mar. 2018). [in English].

Стаття надійшла до редакції 04.04.2019

УДК 378.015.31:159.954-029:7

DOI:

Тетяна Багрій, викладач кафедри теорії і методики музичної освіти та хореографіі Мелітопольського державного педагогічного університету імені Богдана Хмельницького

\section{ВЗАЄМОЗВ'ЯЗОК ПЕДАГОГІЧНИХ ТА АРТИСТИЧНИХЗДІБНОСТЕЙ ЯК НЕОБХІДНА УМОВА ДОСЯГНЕННЯ ПРОФЕСІЙНОГО РОЗВИТКУ МАЙБУТНЬОГО ПЕДАГОГА-МУЗИКАНТА}

У статті розглядаються шляхи реалізаиії актуальних завдань в процесі підготовки майбутнього педагога-музиканта. Автор висвітлює питання взаємодї педагогічних та артистичних здібностей для досягнення творчого розвитку в професійній діяльності. Артистизм розглядається в площині виконавського мистецтвв. Аналізується різна схильність майбутніх фахівців до оволодіння иієї якістю, вплив темпераменту на вияв артистичного обдарування. Визначено шляхи розвитку артистизму засобами диригентсько-хорового мистецтва та його роль у професійному зростанні педагога-музиканта.

Ключові слова: артистизм; диригентсько-хорова діяльність; музикант-педагог; педагогічні та спеціальні здібності; професійна підготовка.

Jim. 9.

Tatyana Bagriy, Lecturer of the Theory and Methodology of Musical Education and Choreography Department Melitopol Bohdan Khmelnytskiy State Pedagogical University

\section{RELATIONSHIP BETWEEN PEDAGOGICALAND ARTSISTIC CHARACTERS AS A NECESSARY CONDITIONS FOR ACHIEVING THE PROFESSIONAL DEVELOPMENT OF THE FUTURE PEDAGOGUE-MUSIC}

The article deals with wais of realization of actual tasks that is examined in the process of of future teacher-musician. Determination of concept "pedagogical capabilities" is given, the feature of developing special flairs of future teacher-musicianis are educed in conductor-choral activity. The professional components of conductor-choir-master are certain. An author exposes the question of cooperation of pedagogical and artistic capabilities for the achievement of creative development in professional activity.

An example of practical model of development of professional internalss of teacher-musician is made and principles of this model are determined. The specific of activity of teacher-musician opens up the question of captur artistry isreasonable as important and necessary quality of future professional activity of teacher-musician. Artistry is examined in to the plane of carrying out art. The examples of different approaches of scientists are set in relation to interpretation of concept to "artistry". Fordetermination of criteria of formed of artistry, an author follows the researches of scientists in this industry. 